\title{
Micropropagation of Bauhinia variegata L. from Tissue Culture
}

\author{
B.M. Singh ${ }^{1}$, C.Wawrosch ${ }^{2}$, S.D. Joshi ${ }^{3}$ and B. Kopp ${ }^{2}$ \\ ${ }^{1}$ Department of Botany, Patan Multiple Campus \\ Patandhoka, Lalitpur \\ ${ }^{2}$ Institute of Pharmacognosy, University of Vienna \\ Austria \\ ${ }^{3}$ Central Department of Botany \\ Tribhuvan University \\ Kirtipur, Kathmandu
}

\begin{abstract}
Bauhinia variegate $\mathrm{L}$. is a multipurpose tree and its micropropagation holds great promise in agroforestry. The sterilized seeds were first inoculated on Murashige and Skoog (MS) medium. Nodal cuttings from these seedlings grown in vitro were used as explants for micropropagation. Nodal cutting inoculated on the medium with various concentrations of BAP (benzyl-aminopurine) and NAA (£- naphthalene acetic acid) and separately generated varied results. Best propagation was recorded on MS medium supplemented with $1.0 \mu \mathrm{MBAP}$ with $0.05 \mu \mathrm{M}$ NAA. Propagated plants were successfully acclimatized and rooted in pots $(6 \mathrm{~cm}$ diameter) containing soil and sand in1:1 ratio and then finally transferred to the field. All the data generated were analysed statistically using SPSS statistical package.
\end{abstract}

Key words: Murashige and Skoog medium, benzyl-aminopurine, naphthalene acetic acid, nodal culture acclimatization.

\section{Introduction}

Bauhinia variegata L. is known as Koiralo in Nepali and belongs to the family Leguminosae. It is found throughout Nepal up to the elevation of $1800 \mathrm{~m}$ (Anonymous 1970). It is a medium sized tree with 5-10 $\mathrm{m}$ height. Leaves are deciduous, deeply cordate, bearing 11-15 prominent nerves. Flowers are large fragrant with white or purplish petals. Flowering takes place during March to April and fruits are ripened in September to November.

Its flowers are edible and very popular in Nepal for preparing curry and pickles. Besides, it has various medicinal properties. The bark is used in dyeing as well as in tanning. The plant is said to yield good fodder to cattle. Decoction of young leaves after boiling is taken to cure stomach trouble. The bark is described as astringent and alternative tonic and useful in scrofula, ulcer, syphilis, leprosy and skin diseases. The bark is also reported to be used as antidote to snake poison and decoction of root is used in dyspepsia (Anonymous 1970). As this tree is with multipurpose value, it is recommended in agro-forestry and for afforestation. In this context, mass propagation of this plant through tissue culture technique holds great promise.

Micro-propagation of plantlets from nodal culture have been reported in many plant species, such as in Ailanthus malabarica D.C., by Silva and Sauza (1992), in Acacia mangium by Bhasker (1996), in Bauhinia vahlii L. by Uprety (1996) and in Acacia mearsii L. by Beck et al. (1998). Although legumes have been found traditionally difficult to regenerate from cell culture, multiplications of $B$. purpurea have been conducted by Kumar (1992). Present investigation is aimed at generating mass propagation technique of $B$. variegata through culture of nodal explants.

\section{Methodology}

The seeds of $B$. variegata were procured from Afforestation Division, Hattisar, Kathamandu, Nepal and were carried to the laboratory of Institute of Pharmacognosy, Vienna, Austria and were preserved at $4^{\circ} \mathrm{C}$ until subsequent experimental use. The healthy seeds were initially washed in water containing few drops of Teepol detergent solution. The seeds were 
then soaked in distilled water for an hour prior to sterilization. The soaked seeds were washed with sterilized distilled water five times. The seeds were then surface sterilized with $30 \%$ ethanol for $10 \mathrm{~min}$, followed by treatment with sodium hypochlorite solution (10\%) for 10 minutes and then rinsed three times with sterilized distilled water. The seeds were again sterilized in $70 \%$ alcohol for one minute and washed with sterile water three times. The seeds were then inoculated on Murashige and Skoog (1962) medium containing $3 \%$ sucrose. The pÇ of the medium was adjusted to $5.8 \pm 1$ before autoclaving at $121^{\circ} \mathrm{C}$ for 20 minutes. The media were solidified by adding $0.8 \%$ agar (Bacteriological). The cultures were maintained at $25 \pm 4^{\circ} \mathrm{C}$ with a photoperiod of $16 \mathrm{~h}\left(40 \mu \mathrm{mol} . \mathrm{m}-{ }^{2} \mathrm{~s}-1\right.$ supplied by OSRAM Biolux tubes) and relative humidity of $70 \%$ in a growth chamber.

The nodal explants $1 \mathrm{~cm}$ long, were excised from the young seedlings and sub-cultured on MS medium supplemented with $0.5 \mu \mathrm{M}$ BAP to obtain sufficient explants needed for subsequent experiments. The explants from these cultures were then used for inoculating MS media having different concentrations of BAP and NAA.

Shoots propagated on the above mentioned medium were cut with nearly 3-4 nodes of 2-3 cm size and transferred for rooting in plastic pots ( $6 \mathrm{~cm}$ diameter) filled with $1: 1$ ratio of sand and soil (Humus-Ton substrate N8). The substrate was soaked with an aqueous solution of the fungicides Benlate and Previcure. The plants were kept at high humidity for initial two weeks; and the humidity was reduced from the second week. The well rooted and acclimatized plants were transferred to the green house for further hardening. All the data generated from this experiment were analysed statistically with SPSS program (Table-1).

Table 1. Effect of different concentrations of BAP and NAA $(\mu \mathrm{M})$ used individually and in combination on shoot regeneration of Bauhinia variegata from nodal explants after 8 weeks of culture (mean \pm SE) Treatments and concentrations $(\mu \mathrm{M})$

\begin{tabular}{|c|c|c|c|}
\hline $\begin{array}{l}\text { Treatments and } \\
\text { concentrations }(\mu \mathrm{M})\end{array}$ & $\begin{array}{l}\text { No.of nodes } \\
(\text { Mean } \pm \mathrm{SE})\end{array}$ & $\begin{array}{l}\text { Shoot length }(\mathrm{mm}) \\
\text { (Mean } \pm \text { SE) }\end{array}$ & $\begin{array}{l}\text { ö Calli (mm) } \\
(\text { Mean } \pm \text { SE) }\end{array}$ \\
\hline \multicolumn{4}{|l|}{ BAP } \\
\hline $0.5+0$ & $6,25 \pm 0.3$ & $52.80 \pm 3.0$ & $9.95 \pm 0.5$ \\
\hline $1.0+0$ & $4.75 \pm 0.3$ & $46.80 \pm 2.8$ & $9.25 \pm 0.5$ \\
\hline $2.0+0$ & $4.65 \pm 0.3$ & $51.35 \pm 4.8$ & $11.65 \pm 0.4$ \\
\hline $5.0+0$ & $4.20 \pm 0.3$ & $38.00 \pm 3.3$ & $16.75 \pm 0.7$ \\
\hline \multicolumn{4}{|l|}{ NAA } \\
\hline $0+0.1$ & $2.60 \pm 0.3$ & $15.66 \pm 1.2$ & $0.00 \pm 0.0$ \\
\hline $0+0.5$ & $3.10 \pm 0.3$ & $17.15 \pm 1.8$ & $0.00 \pm 0.0$ \\
\hline $0 .+1.0$ & $3.05 \pm 0.2$ & $18.45 \pm 1.1$ & $0.00 \pm 0.0$ \\
\hline $0+2.0$ & $2-65 \pm 0.3$ & $13.75 \pm 1.1$ & $0.00 \pm 0.0$ \\
\hline \multicolumn{4}{|l|}{$\mathrm{BAP}+\mathrm{NAA}$} \\
\hline $0.10+0.05$ & $5.50 \pm 0.4$ & $51.30 \pm 4.0$ & $7.85 \pm 0.4$ \\
\hline $0.25+0.05$ & $6.65 \pm 0.3$ & $65.45 \pm 4.6$ & $9.80 \pm 0.2$ \\
\hline $0.50+0.05$ & $7.00 \pm 0.3$ & $60.70 \pm 2.8$ & $9.85 \pm 0.3$ \\
\hline $1.0+0.05$ & $7.45 \pm 0.6$ & $63.30 \pm 5.3$ & $10.20 \pm 0.4$ \\
\hline $0.1+0.5$ & $4.00 \pm 0.3$ & $28.00 \pm 3.8$ & $7.85 \pm 0.5$ \\
\hline $0.25+0.5$ & $6.15 \pm 0.3$ & $62.05 \pm 4.5$ & $9.30 \pm 0.2$ \\
\hline $0.5+0.5$ & $6.40 \pm 0.4$ & $60.50 \pm 5.1$ & $9.35 \pm 0.2$ \\
\hline $1.0+0.5$ & $6.60 \pm 0.4$ & $56.45 \pm 3.7$ & $9.35 \pm 0.2$ \\
\hline $0.1+1.0$ & $5.60 \pm 0.3$ & $39.05 \pm 4.2$ & $8.45 \pm 0.2$ \\
\hline $0.25+1.0$ & $5.00 \pm 0.3$ & $40.00 \pm 4.0$ & $8.00 \pm 0.2$ \\
\hline $0.50+1.0$ & $6.40 \pm 0.4$ & $54.00 \pm 4.5$ & $10.00 \pm 0.3$ \\
\hline $1.0+1.0$ & $5.80 \pm 0.4$ & $48.80 \pm 3.9$ & $9.55 \pm 0.4$ \\
\hline control & $3.85 \pm 0.2$ & $18.20 \pm 1.3$ & $0.00 \pm 0.0$ \\
\hline
\end{tabular}




\section{Results and Discussion}

Of the various treatments assessed having individual and combined BAP and NAA concentration, MS medium supplemented with $1.0 \mu \mathrm{M}$ BAP and $0.05 \mu \mathrm{M}$ NAA produced highest number of nodes, (7.45 \pm 0.6$)$,

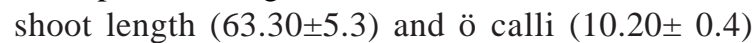
(Table 1), (Fig. 1). About 60-65 mm shoot length and 6.65 nodes were observed on MS medium supplemented with $0.25 \mu \mathrm{M}$ BAP and $0.05 \mu \mathrm{M}$ NAA (Fig. 2). With increasing concentrations of BAP in the initiation of calli were also found increasing in media supplemented with BAP alone or combined BAP and NAA. MS medium supplemented with $0.1,0.25,0.5$ and $1.0 \mu \mathrm{M}$ BAP each with $0.5 \mu \mathrm{M}$ NAA also initiated good regeneration of nodes and increase in shoot length. Among all the experiments, the best multiplication of nodes and increased shoot length were recorded on MS medium supplemented with $1.0 \mu \mathrm{M}$ BAP and 0.5 $\mu \mathrm{M}$ NAA. In the same way high multiplication of nodes and increased shoot length were recorded on MS medium with $0.25 \mu \mathrm{M}$ BAP and $0.5 \mu \mathrm{M}$ NAA. Last treatment of $1.0 \mu \mathrm{M}$ NAA with factorial combinations of BAP showed slightly less shoot numbers than in former media.

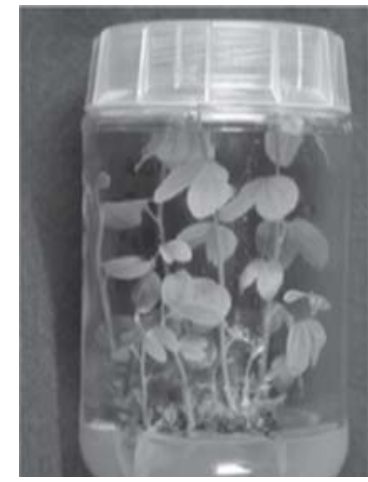

Fig.1. Shoot proliferation of MS medium $+1.0 \mu \mathrm{M}$ $\mathrm{BAP}+0.05 \mu \mathrm{M}$ NAA $B$. variegata on the

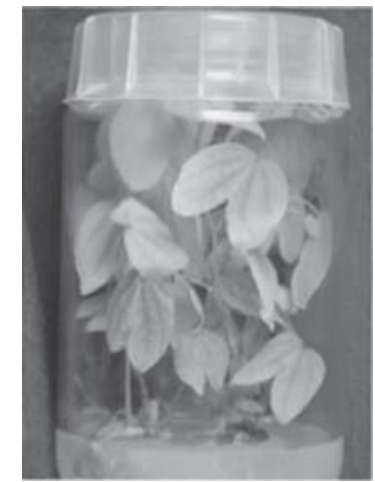

Fig.2. Shoot proliferation of B.variegata on the MS medium $+0.25 \mu \mathrm{M}$ $\mathrm{BAP}+0.05 \mu \mathrm{M}$ NAA
Few people have worked in Bauhinia spp. tissue culture. In vitro propagation of B. purpurea (Kumar 1992) and B. variegata (Mathur \& Mukunthakumar 1992) was successful from nodal segments on MS medium with 13.3 $\mu$ M BAP. Bhatta and Dhar (2000) regenerated $B$. vahlii using seedling explants on MS medium supplemented with thidiazuron and kinetin (1.0 $\mu \mathrm{M}$ each).

Our results corroborate with the above results in which low concentrations of BAP from 0.5 to $1.0 \mu \mathrm{M}$ favored best propagation of shoots and nodes. So the present investigation suggests that the concentrations $1.0 \mu \mathrm{M}$ BAP and $0.05 \mu \mathrm{M}$ NAA are suitable for the propagation of $B$. variegata plants.

\section{Acknowledgements}

We would like to acknowledge the Central Department of Botany, Tribhuvan University for providing the materials and other supports for the research. We also acknowledge The Institute of Pharmacognosy, University of Vienna, for providing opportunity to conduct experimental parts of the research work. Authors are also thankful to Austrian Academic Exchange Service (ÖAD) which provided the fellowship to partly support this research.

\section{References}

Anonymous.1970. Medicinal plants of Nepal. Bulletin of the Department of Medicinal Plants No. 3.

Beck, S.L., R. Dunlop and J.V. Staden. 1998. Micropropagation of Acacia mearnsii from ex vitro material. Plant Growth Regulators 26:143-148.

Bhasker, P. and K. Subhas. 1996. Micropropagation of Acacia mangium Wild through nodal bud culture. Indian Journal of Experimental Biology 34: 590-591.

Bhatta, I.D. and U. Dhar. 2000. Combined effect of cytokininon multiple shoot production from cotyledonary node explants of Bauhinia vahlii. Plant Cell Tissue Culture and Organ Culture 62: 79-83.

Kumar, A. 1992. Micropropagation of a mature leguminous tree- Bauhinia purpurea. Plant Cell Tissue and Organ Culture 31:257-259.

Mathur, J. and S. Mukunthakumar. 1992. Micropropagation of Bauhinia variegata and Parkinsonia aculeata from nodal explants of mature trees. Plant Cell Tissue and Organ Culture 28:119-121.

Silva, I.D. and L.D. Souza. 1992a. Micropropagation of Ailanthus malabarica D.C. using juvenile and mature tree tissues. Silvae Genetica 41: 6.

Upreti, J. and U. Dhar. 1996. Micropropagation of Bauhinia vahlii Wight \& Arnott- A leguminous liana. Plant Cell Reports 16:250-254. 
Nepal Journal of Science and Technology Vol. 13, No. 1 (2012) 